Иркутский национальный исследовательский технический университет, г. Иркутск, Российская федераиия

А. В. Мартынюк

Иркутский национальный исследовательский технический университет, г. Иркутск, Российская федерация

\title{
УПРАВЛЕНИЕ РИСКАМИ НА ЭТАПЕ ПРОЕКТИРОВАНИЯ ОБЪЕКТОВ ПЕРЕРАБОТКИ НЕФТИ И ГАЗА
}

\begin{abstract}
АНнотАция. Российская Федерация обладает обширным запасом топливно-энергетических ресурсов, незначительный объем которых, по сравнению с долей экспорта, направляется для переработки на нефте- и газоперерабатывающие заводы. Данные объекты относятся к категории взрывопожароопасных, и их деятельность связана с риском для жизни и здоровья работников, а также населения, живущего в границах расположения опасного объекта. Для минимизации рисков предприятиями создаются газоспасательные, пожарные службы, команды оперативного реагирования, приобретаются роботизированные комплексы тушения пожаров на площадке хранения опасных продуктов и т. д. Перечисленные меры предназначены для устранения последствий наступления неблагоприятного события. Любое событие, носящее чрезвычайный характер, легче предупредить, чем устранить. В статье рассматривается значение топливно-энергетических ресурсов для России, сравниваются показатели аварийности за прошедшие годы на объектах нефтепереработки, анализируются методы управления рисками, применяемые на этапе проектирования опасных производственных объектов. Обосновывается предложение по использованию методов HAZOP и HAZID в дополнение к применяемым на территории России планам по локализации и ликвидации чрезвычайных ситуаций (План локализации и ликвидации аварий, План локализации и ликвидации аварийных ситуаций, План по локализации и ликвидации аварийных разливов нефти и нефтепродуктов).
\end{abstract}

кЛЮчЕВЫЕ СЛОВА. Риск; проектирование; нефтеперерабатывающий завод; метод HAZOP; метод HAZID.

ИНФОРМАЦИЯ О СТАТЬЕ. Дата поступления 18 января 2016 г.; дата принятия к печати 26 февраля 2016 г.; дата онлайн-размещения 31 марта 2016 г.

N. G. Urazova

Irkutsk National Research Technical University, Irkutsk, Russian Federation

A.V. Martynyuk

Irkutsk National Research Technical University, Irkutsk, Russian Federation

\section{RISK MANAGEMENT AT THE STAGE OF DESIGNING FACILITIES OF RUDE OIL AND GAS PROCESSING}

\begin{abstract}
Russia has vast reserves of fuel and energy resources, an insignificant volume of which, as compared with the export share, is directed for processing to oil and gas refineries. These facilities are referred to the category of the fire and explosion dangerous one, and their activity is connected with risk for life and health of workers and the population living within the boundaries of a hazardous facility location. To minimize these risks, companies build up gas rescue, fire services, rapid response teams, purchase robotic systems of fire extinguishing at the site of dangerous products storage, etc. The listed measures are designed to eliminate the consequences of an ad-
\end{abstract}

(C) Н. Г. Уразова, М. В. Мартынюк, 2016

\section{Baikal Research Journal}


verse event occurrence. Any event that bears extraordinary nature is easier to prevent than to eliminate. This article considers the importance of fuel and energy resources for Russia, compares the accident rates over the years at refining facilities and analyzes the risk management methods used in the design phase of hazardous production facilities. It substantiates proposals on using the HAZOP and HAZID methods in addition to the plans of localization and liquidation of emergency situations applied on the territory of the Russian Federation ( "Plan of localization and liquidation of accidents» , "Plan of localization and liquidation of accident situations», "Plan of localization and liquidation of emergency oil and oil products spills»).

KEYWORDS. Risk; designing; refinery; HAZOP method; HAZID method.

ARTICLE INFO. Received January 18, 2016; accepted February 26, 2016; available online March 31, 2016.

Развитие экономики России в значительной степени зависит от состояния нефтегазового комплекса, который на сегодняшний день переживает кризис. Стоимость нефти снизилась за 2015 г. практически в 2 раза - с максимума 68,39 дол. за баррель в мае 2015 г. до минимума 36,2 дол. за баррель в декабре.

Однако по-прежнему топливно-энергетический комплекс обеспечивает значительный вклад в формирование положительного торгового баланса и налоговых поступлений в бюджеты всех уровней. Этот вклад существенно выше доли промышленного комплекса. На долю нефтяного комплекса приходится более 16 \% произведенного валового внутреннего продукта России, четвертая часть налоговых поступлений, а также более трети поступающей в Россию валютной выручки. Такие высокие показатели связаны со значительным ресурсным и производственным потенциалом нефтяной отрасли. В недрах России сосредоточено около $13 \%$ разведанных запасов нефти. Примерно $60 \%$ ресурсов нефти приходится на долю районов Урала и Сибири, что создает потенциальные возможности экспорта как в западном, так и в восточном направлениях [1].

Значение нефтедобывающей и нефтеперерабатывающей промышленности в экономике России чрезвычайно велико, что обусловлено, в первую очередь, высокой степенью концентрации значительного объема мировых ресурсов нефти на территории страны.

На топливно-энергетические ресурсы в структуре экспорта товаров России приходится наибольшая доля (45 \%) [2]. Анализируя структуру экспорта за 2014 г., было выявлено, что на топливно-энергетические ресурсы приходится: поставка сырой нефти $-52,2 \%$, нефтепродуктов $-30 \%$ и природного газа $-17,8 \%{ }^{1}$.

Данное соотношение говорит о сохранении на высоком уровне (больше 50 \%) тенденции поставок за границу сырой нефти, подверженной влиянию рыночных колебаний, в то время как переработка попутного нефтяного газа (ПНГ) на нефтеперерабатывающих заводах (НПЗ) позволяет компаниям снизить зависимость от высокой ценовой волатильности на рынке нефти и улучшить свои конкурентные позиции путем выпуска и реализации высококачественной продукции с высокой добавленной стоимостью [3].

Однако нефтяной промышленности, как и многим другим отраслям производства, присущи риски, которые могут быть связаны с ресурсами, как материальными, так и человеческими; процессами производства, рынком, а также иными внутренними и внешними факторами. Следствиями наступления неблагоприятных рисковых ситуаций являются потери компании. Поскольку нефтяная промышленность играет значительную роль в экономике России, то эти потери могут быть весь-

${ }^{1}$ Мониторинг «Об итогах социально-экономического развития Российской Федерации в январе-ноябре 2014 года». URL : http://economy.gov.ru/minec/activity/sections/macro/monitoring/201407251.

\section{Baikal Research Journal}


ма существенными. Для снижения их вероятности компании необходимо развивать риск-менеджмент.

По состоянию на 2015 г. в соответствии с данными Министерства энергетики Российской Федерации, введено в эксплуатацию 37 заводов, проектируется 27 и строится 3 нефтеперерабатывающих завода ${ }^{2}$. Средние значения глубины переработки нефти на НПЗ приведены на рис. 1.

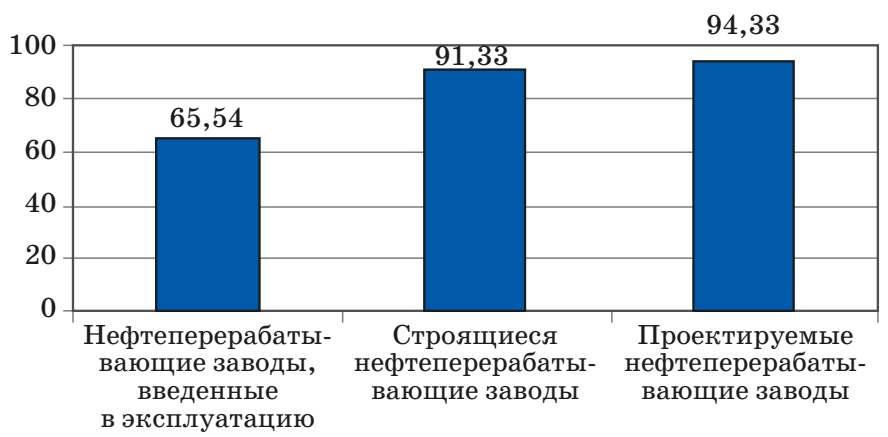

Рис. 1. Глубина переработки нефти на нефтеперерабатывающих заводах, \%

К строительству НПЗ косвенно обязывает постановление «О мерах по стимулированию сокращения загрязнения атмосферного воздуха продуктами сжигания попутного нефтяного газа на факельных установках» от 8 января 2009 г. № 7 , которое устанавливает целевой показатель сжигания ПНГ на факелах на 2012 и последующие годы в размере не более 5 \% от объема добытого попутного газа. Повышение платы за сверхлимитное сжигание ПНГ началось с 1 января 2012 г., причем при расчете этой платы будет применяться дополнительный коэффициент 4,5. Кроме того, с 1 января 2012 г. при отсутствии средств измерения и учета, подтверждающих фактический объем образования, использования и сжигания на факельных установках ПНГ, дополнительный коэффициент будет уже $6,0^{3}$. При этом доля утилизации ПНГ в России за 2010-2013 гг. колеблется в пределах $76 \%$ [4; 5]. По прогнозам Агентства экономической информации «Прайм», утилизация ПНГ в 2016 г. достигнет значения $93,7 \%{ }^{4}$. Для обеспечения достижения целевого показателя 95 \% компании могут использовать следующие способы утилизации ПНГ (табл. 1).

В России из представленных методов наиболее распространено строительство НПЗ, так как это позволяет компаниям, произведя глубокую переработку сырой нефти, получить более ценный продукт. При этом данный метод представляет из указанных (см. табл. 1) наибольшую опасность в связи с тем, что на заводе перерабатывается взрывопожароопасная продукция, а учитывая то, что на заводе могут трудиться до нескольких тысяч человек, последствия аварии могут быть фатальными.

2 Реестр проектируемых, строящихся и введенных в эксплуатацию нефтеперерабатывающих заводов в Российской Федерации. Министерство энергетики Российской Федерации. URL : http:// minenergo.gov.ru/activity/oil/reestr_npz/.

3 Утилизация попутного нефтяного газа: дискуссии продолжаются. URL : http://ria.ru/ economy/20120321/602177511.html.

${ }^{4}$ Уровень утилизации ПНГ нефтекомпаниями РФ к 2016 г достигнет 93,7\% // Агентство экономической информации «Прайм». URL : http://1 prime.ru/companies/20131225/773962438.html.

\section{Baikal Research Journal}


Способы утилизации попутного нефтяного газа и их приленение на российских предприятиях нефтяной пролышленности

\begin{tabular}{|c|c|c|}
\hline Способ & Применение & Источник \\
\hline $\begin{array}{l}\text { Сбор и транспорти- } \\
\text { ровка по трубопрово- } \\
\text { дам на газоперераба- } \\
\text { тывающие заводы }\end{array}$ & $\begin{array}{l}\text { ЗАО «Антипинский НПЗ», ОАО «АНХК», } \\
\text { ООО «РН-Комсомольский НПЗ», } \\
\text { ОАО «Газпромнефть - Московский НПЗ», } \\
\text { ОАО «Хабаровский НПЗ», ОАО «Саратовский } \\
\text { НПЗ» }\end{array}$ & - \\
\hline $\begin{array}{l}\text { Использование } \\
\text { неподготовленного } \\
\text { («жирного») газа в } \\
\text { котельных }\end{array}$ & $\begin{array}{l}\text { Автономная котельная с уличным размещени- } \\
\text { ем теплогенераторов пульсирующего горения, } \\
\text { ОАО «Камбарский завод газового оборудования» } \\
\text { (г. Камбарка, Удмуртская Республика) }\end{array}$ & - \\
\hline $\begin{array}{l}\text { Закачка попутного } \\
\text { нефтяного газа с } \\
\text { помощью компрес- } \\
\text { сорных установок } \\
\text { сайклинг-процесса } \\
\text { под пласт, что способ- } \\
\text { ствует увеличению } \\
\text { нефтеотдачи пласта }\end{array}$ & $\begin{array}{l}\text { Первый в России проект по добыче газового } \\
\text { конденсата с обратной закачкой газа в пласт } \\
\text { стартовал в ООО «Иркутская нефтяная компа- } \\
\text { ния». Проектные работы по реализации проекта } \\
\text { начались в } 2007 \text { г., в практическую фазу проект } \\
\text { вступил в } 2009 \text { г. Была закуплена первая ком- } \\
\text { прессорная установка мощностью } 1 \text { млн м }{ }^{3} \text { газа. } \\
\text { Проект предусматривает дальнейшее увеличение } \\
\text { объема закачки газа до } 6 \text { млн м }{ }^{3} \text { в сутки }\end{array}$ & $\begin{array}{l}\text { Первый в России } \\
\text { проект по обратной } \\
\text { закачке газа в пласт } \\
\text { стартовал в Приан- } \\
\text { гарье. URL : http:// } \\
\text { bratsk.org/news/ } \\
\text { show/10235.html }\end{array}$ \\
\hline $\begin{array}{l}\text { Хранение в подзем- } \\
\text { ном хранилище газа }\end{array}$ & $\begin{array}{l}\text { ПАО «Газпром», запустивший первое подоб- } \\
\text { ное хранилище газа в России, расположенное в } \\
\text { соляных кавернах в Калининградской области, } \\
\text { запустил }\end{array}$ & $\begin{array}{l}\text { «Газпром» ввел } \\
\text { в эксплуатацию } \\
\text { Калининградское } \\
\text { ПХГ. URL : http:// } \\
\text { www.gazprom.ru/ } \\
\text { press/news/2013/ } \\
\text { september/arti- } \\
\text { cle171931 }\end{array}$ \\
\hline $\begin{array}{l}\text { Производство элек- } \\
\text { трической и тепловой } \\
\text { энергии в газотурбин- } \\
\text { ных и газопоршневых } \\
\text { электростанциях с } \\
\text { системами утилиза- } \\
\text { ции тепла }\end{array}$ & $\begin{array}{l}\text { Для примера, по данным замеров и проб на } \\
\text { территории факельного хозяйства УППН «Куе- } \\
\text { да» ЦДНГ-2 ООО ЭЛУКОЙЛ-Пермь» в качестве } \\
\text { топлива для газотурбинных электроагрегатов } \\
\text { газовой электростанции применяется метан, доля } \\
\text { которого составляет } 64 \text { \% всего объема попутного } \\
\text { нефтяного газа }\end{array}$ & $\begin{array}{c}\text { В Госдуму внесен } \\
\text { законопроект о } \\
\text { приоритетном } \\
\text { доступе на оптовый } \\
\text { рынок электроэнер- } \\
\text { гии, произведен- } \\
\text { ной из ПНГ. URL: } \\
\text { http://www.rbc. } \\
\text { ru/rbcfreenews/ } \\
\text { 20090812114415. } \\
\text { shtml }\end{array}$ \\
\hline $\begin{array}{l}\text { Переработка попут- } \\
\text { ного нефтяного газа } \\
\text { на месте добычи с ис- } \\
\text { пользованием метода } \\
\text { криогенного разделе-- } \\
\text { ния на фракции }\end{array}$ & $\begin{array}{l}\text { Строительство модульных комплексов для } \\
\text { выработки электрической и тепловой энергии и } \\
\text { получения сжиженных углеводородных газов } \\
\text { Одна из последних разработок в сфере криогенной } \\
\text { технологии - FlareRec, которая используется в } \\
\text { работе аварийных генераторов на основе горюче- } \\
\text { го, также она позволяет сжижать и подавать газ } \\
\text { к обособленно расположенным объектам (напри- } \\
\text { мер, отдаленным базам). Кроме того, ее исполь- } \\
\text { зуют при выделении продуктов из факельных } \\
\text { газов (например, CNG - сжатый природный газ, } \\
\text { LNG - сжиженный природный газ, LPG - сжи- } \\
\text { женные углеводородные газы) }\end{array}$ & $\begin{array}{l}\text { Утилизация } \\
\text { попутного нефтя- } \\
\text { ного газа ПНГ. } \\
\text { URL : http://www. } \\
\text { alliance-energy.ru/ } \\
\text { utilizaciya-poputno- } \\
\text { go-neftyanogo-ga- } \\
\text { za-mestorozhdenij }\end{array}$ \\
\hline
\end{tabular}

Анализ статистических данных Федеральной службы по экологическому, технологическому и атомному надзору [6] позволил выявить число аварий на объектах нефтепереработки и нефтехимии (табл. 2).

\section{Baikal Research Journal}


Таблица 2

Распределение аварий по отраслям промышленности в 2012-2013 22.

\begin{tabular}{|l|r|r|}
\hline \multicolumn{1}{|c|}{ Отрасли промышленности } & 2012 & 2013 \\
\hline Нефтегазоперерабатывающая & 11 & 8 \\
\hline Нефтехимическая & 3 & 1 \\
\hline Объекты нефтепродуктообеспечения & 4 & 5 \\
\hline Всего & 18 & 14 \\
\hline
\end{tabular}

В 2013 г. уменьшилось количество аварий на опасных производственных объектах нефтеперерабатывающей (-3) и нефтехимической (-2) промышленности и увеличилось на объектах нефтепродуктообеспечения (+1). Несмотря на то, что количество аварий снизилось, их последствия оказались существенными.

Мониторинг соблюдения требований промышленной безопасности показывает, что при эксплуатации опасных производственных объектов являются следующие нарушения:

- отсутствие оснащения объектов средствами контроля, противоаварийной защиты;

- необеспеченность герметичности технологических систем;

- отсутствие быстродействующих запорных устройств на трубопроводах;

- нарушения организации и осуществления производственного контроля;

- несоблюдение сроков проведения экспертизы промышленной безопасности технических устройств;

- неисполнение порядка ведения эксплуатационной документации.

Для предотвращения аварийности, повышения безопасности инженерно-технических систем и сооружений на опасных производственных объектах, обеспечения устойчивости и безопасности функционирования поднадзорных объектов в чрезвычайных ситуациях на предприятиях предусмотрены планы локализации и ликвидации аварий (ПЛА), планы локализации и ликвидации аварийных ситуаций (ПЛАС), а также планы по локализации и ликвидации аварийных разливов нефти и нефтепродуктов (ПЛАРН), сравнение основных характеристик которых приведено в табл. 3.

Сравнение планов по локализации и ликвидации чрезвычайных ситуаций

\begin{tabular}{|c|c|c|c|}
\hline Параметр & $\begin{array}{c}\text { Планы локализа- } \\
\text { ции и ликвидации } \\
\text { аварий } \\
\end{array}$ & $\begin{array}{c}\text { Планы локализации } \\
\text { и ликвидации } \\
\text { аварийных ситуаций }\end{array}$ & $\begin{array}{c}\text { Планы по локализации и ликвидации } \\
\text { аварийных разливов нефти и нефтепро- } \\
\text { дуктов }\end{array}$ \\
\hline $\begin{array}{l}\text { Целевые } \\
\text { объекты }\end{array}$ & Все ОПО & $\begin{array}{l}\text { Химико-технологиче- } \\
\text { ские объекты }\end{array}$ & $\begin{array}{l}\text { Организации, осуществляющие раз- } \\
\text { ведку месторождений, добычу нефти, а } \\
\text { также переработку, транспортировку, } \\
\text { хранение нефти и нефтепродуктов }\end{array}$ \\
\hline Цель & $\begin{array}{l}\text { Определить } \\
\text { оперативные дей- } \\
\text { ствия персонала по } \\
\text { предотвращению } \\
\text { и локализации } \\
\text { аварий }\end{array}$ & $\begin{array}{l}\text { Определить воз- } \\
\text { можные сценарии } \\
\text { возникновения ава- } \\
\text { рийной ситуации и ее } \\
\text { развития }\end{array}$ & $\begin{array}{l}\text { Спрогнозировать возможные разливы } \\
\text { нефти и нефтепродуктов, определить } \\
\text { количество сил и средств, достаточных } \\
\text { для ликвидации чрезвычайных ситу- } \\
\text { аций, связанных с разливом нефти и } \\
\text { нефтепродуктов }\end{array}$ \\
\hline \begin{tabular}{|l} 
Итого- \\
вый план
\end{tabular} & $\begin{array}{l}\text { Сформированный } \\
\text { план действий } \\
\text { по исключению } \\
\text { (минимизации) } \\
\text { возможности заго- } \\
\text { раний и взрывов, } \\
\text { снижения тяжести } \\
\text { возможных по- } \\
\text { следствий аварий }\end{array}$ & $\begin{array}{l}\text { Сформированный } \\
\text { план действий } \\
\text { производственного } \\
\text { персонала и ава- } \\
\text { рийно-спасательных } \\
\text { служб по локализа- } \\
\text { ции и ликвидации } \\
\text { аварийных ситуаций } \\
\text { на соответствующих } \\
\text { стадиях их развития }\end{array}$ & $\begin{array}{l}\text { План обеспечения постоянной го- } \\
\text { товности сил и средств с указанием } \\
\text { организаций, которые несут ответствен- } \\
\text { ность за их поддержание в установлен- } \\
\text { ной степени готовности, а также график } \\
\text { проведения операций по ликвидации } \\
\text { разливов нефти и нефтепродуктов }\end{array}$ \\
\hline
\end{tabular}

\section{Baikal Research Journal}

электронный научный журнал Байкальского государственного университета 
В имеющихся ПЛА и ПЛАРН содержатся данные по созданию на предприятиях резервов материальных и финансовых ресурсов для выполнения мероприятий по предупреждению и ликвидации чрезвычайных ситуаций, описание действий персонала при возникновении и развитии аварии, готовность к действиям по локализации и ликвидации аварий, спасению людей.

Разработка ПЛА и ПЛАС - обязательная задача для любого предприятия, эксплуатирующего опасный производственных объект с возможностью возникновения аварий, которые повлекут за собой накопление ядовитых газов, пожары или взрывы.

Для организаций, работающих с нефтью, процедура разработки и согласования ПЛАРН является обязательным требованием промышленной безопасности. ПЛАРН - обязательный документ для оформления лицензии Ростехнадзора на эксплуатацию химически опасных и взрывопожароопасных производственных объектов I-III классов опасности. Данные мероприятия разрабатываются с целью снижения риска аварийности на опасных производственных объектах. Помимо данных мероприятий предприятия добровольно применяют методы управления рисками, которые позволяют им снизить вероятность аварийности, обеспечивая потенциальное сохранение ресурсов от ущерба, который компания могла бы понести в случае реализации риска $[7 ; 8]$.

Одними из наиболее детализированных анализов ${ }^{5}$, по нашему мнению, являются методы HAZID и HAZOP (табл. 4).

Memoды HAZID и HAZOP

Таблица 4

\begin{tabular}{|c|c|c|}
\hline Параметр & HAZID & HAZOP \\
\hline Определение & Идентификация опасности & $\begin{array}{l}\text { Исследование опасности и работо- } \\
\text { способности }\end{array}$ \\
\hline $\begin{array}{l}\text { Регламентирую- } \\
\text { щий стандарт }\end{array}$ & ГОСТ Р 51901.1-2002 (МЭК) & $\begin{array}{l}\text { ГОСТ Р 51901.11-2005 (МЭК } \\
61882: 2001)\end{array}$ \\
\hline Цель & $\begin{array}{l}\text { Приемлемо ли использовать проектируе- } \\
\text { мые методы и оборудование для реализа- } \\
\text { ции объекта, или они требуют внесения } \\
\text { изменений }\end{array}$ & $\begin{array}{l}\text { Приемлемо ли использовать } \\
\text { текущие методы и оборудование } \\
\text { для реализации объекта, или они } \\
\text { требуют внесения изменений }\end{array}$ \\
\hline Этап проведения & $\begin{array}{l}\text { HAZID проводится после завершения } \\
\text { разработки концепции системы и перед } \\
\text { началом разработки основных техни- } \\
\text { ческих решений в начале проектиро- } \\
\text { вания объекта (выбор площадки, кон- } \\
\text { структивные решения, размещение и } \\
\text { подбор оборудования) }\end{array}$ & $\begin{array}{l}\text { Исследования HAZOP проводятся } \\
\text { на этапе проектирования (при } \\
\text { проверке проектных решений) и } \\
\text { на этапе опытной эксплуатации } \\
\text { (при оценке безопасности и на- } \\
\text { дежности существующего завода) }\end{array}$ \\
\hline $\begin{array}{l}\text { Сущность ме- } \\
\text { тода }\end{array}$ & $\begin{array}{l}\text { По каждому элементу указываются } \\
\text { опасности (которые ранжируются по } \\
\text { возможным последствиям, при этом } \\
\text { используются три категории - большая, } \\
\text { средняя, низкая), оценивается частота их } \\
\text { реализации на объекте (три категории - } \\
\text { большая, средняя, низкая) }\end{array}$ & $\begin{array}{l}\text { Сущность метода состоит в вы- } \\
\text { делении части технологического } \\
\text { процесса (технологических си- } \\
\text { стем - участков, узлов объекта) } \\
\text { и его детальном рассмотрении } \\
\text { группой экспертов с докумен- } \\
\text { тированием обнаруженных } \\
\text { проблем }\end{array}$ \\
\hline
\end{tabular}

Составлено по: [9].

${ }^{5}$ Международная конференция «Управление рисками на объектах нефтегазового комплекса на основе применения международных стандартов». URL : http://oilgas-expo.com/static/content/img_ $\operatorname{razdel} /$ demo/3/10.pdf.

\section{Baikal Research Journal}


Для лучшего понимания сущности методик рассмотрим пример анализа, проводимого с помощью данных методов, на терминале компании «Сахалин Энерджи» .

Процедура HAZID. Цель - выявление потенциальных опасностей и рисков на начальном этапе проектирования Терминала. Участники - Сахалин Энерджи (заказчик проекта, эксплуатирующая организация), «НИПИгазпереработка» (проектная организация), НТЦ «Промышленная безопасность» (экспертная организация). Форма проведения - оперативные совещания (сессии) группы многопрофильных специалистов (8-10 чел.) в течение трех дней в форме «мозгового штурма» с протоколированием результатов обсуждения. Схема процедуры HAZID приведена на рис. 2.

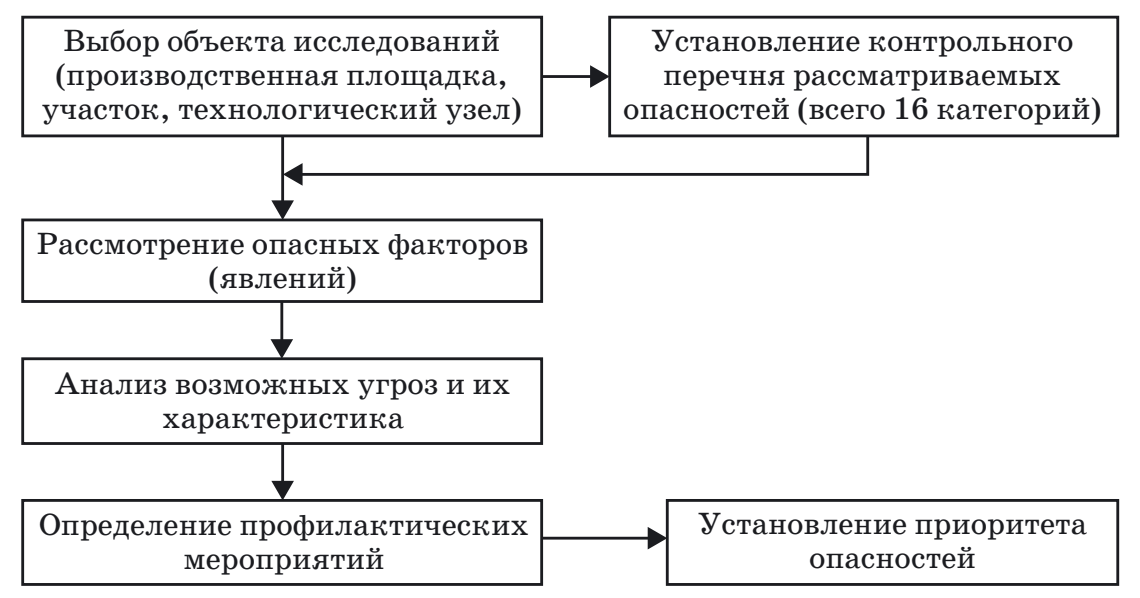

Puc. 2. Схема процедуры НAZID

Используя контрольный перечень опасностей (рис. 3), составляется рабочая ведомость [10; 11], в которой указываются:

- наименования опасных факторов (например, высокая и низкая температура);

- последствия факторов (например, отказ оборудования, разгерметизация трубопроводов и оборудования, выброс газа, авария, материальный ущерб, экономические потери);

- угрозы - на что фактор может оказать влияние (например, потеря рабочих характеристик смазочных материалов, элементов аппаратуры, образование пробок в линиях сброса газа);

- мероприятия по уменьшению опасности (например, выбор материалов, проработка стратегии технического обслуживания, укрытие от воздействия прямых солнечных лучей, обогрев бокса газодизельных электростанций; климатизация помещений, теплоизоляция оборудования; обогрев теплоспутниками трубопроводов и оборудования);

- приоритет риска, устанавливаемый по принятой упрощенной шкале: 1 - высокий (неприемлемый) риск; $2-$ средний риск; 3 - низкий риск [12];

- примечания (например, уточнить вопрос теплоизоляции оборудования, отопление, климатологию блок-боксов, инженерные изыскания).

Таким образом, используя процедуру HAZID, добиваются уточнения следующих исходных данных: удаленность от населенных пунктов; порядок действия персонала при пуске и наладке технических систем терминала; принципы аварийного отключения.

\section{Baikal Research Journal}




\begin{tabular}{|l|}
\hline $\begin{array}{c}\text { Внешние и экологические } \\
\text { риски }\end{array}$ \\
\hline \multicolumn{1}{|c}{ Опасности стихийных } \\
бедствий и вредных \\
факторов окружающей \\
среды \\
Антропогенные риски \\
Воздействие технологи- \\
ческого объекта на \\
окружающую местность \\
Инфраструктура \\
Ущерб окружающей \\
среде
\end{tabular}

Рис. 3. Контрольный перечень опасностей (Составлено по: [9])

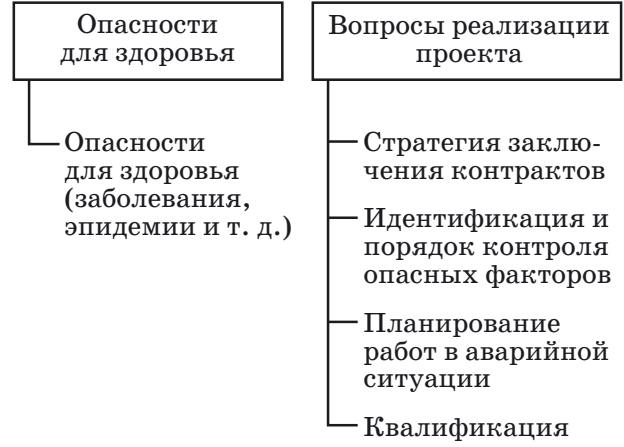

Опасные факторы технического обслуживания

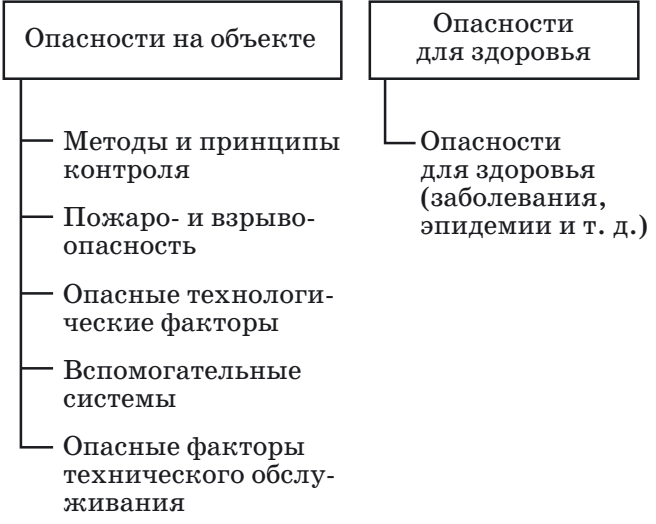

валификация

Процедура НAZOP. Цель - анализ отклонений технологических параметров от регламентных (допустимых). Составные части терминала: участок трубопровода (отвод от магистрального газопровода); система фильтрации и сепарации газа; система замера, дозирования и регулирования потока газа; система электроснабжения терминала; дренажная система. Объект исследования - первоначальная проектная документация по составным частям терминала. Уровень риска (приоритет): 1 - высокий (неприемлемый) риск; 2 - средний риск; 3 - низкий риск. Для того, чтобы показать изменение параметра, применяют управляющие слова (табл. 5).

Таблица 5

Значения управляющих слов

\begin{tabular}{|l|l|}
\hline \multicolumn{1}{|c|}{ Управляющее слово } & \multicolumn{1}{|c|}{ Значение } \\
\hline Меньше & $\begin{array}{l}\text { Количественное уменьшение параметра, например снижение тем- } \\
\text { пературы }\end{array}$ \\
\hline Обратно & $\begin{array}{l}\text { Изменение параметра на противоположное, например, обратный } \\
\text { поток газа, открытие клапана вместо закрытия }\end{array}$ \\
\hline Иначе, Чем также, Как & $\begin{array}{l}\text { Выполнение другого действия, изменение другого параметра, на- } \\
\text { пример изменение состава газа }\end{array}$ \\
\hline Другое & $\begin{array}{l}\text { Действие, отличающееся от проектного назначения, результат не } \\
\text { соответствует первоначальной цели, например, сбои в подаче элек- } \\
\text { троэнергии }\end{array}$ \\
\hline
\end{tabular}

Результаты исследований терминала методом HAZOP формируются в форме рабочего листа (табл. 6 ).

Результаты исследования терминала методом HAZOP следующие:

- степень фильтрации газа (упрощение, надежность, удешевление);

- автоматизация дренирования жидкой фазы из фильтра;

- размещение узла дозирования в закрытом помещении;

- исключение введения метанола в трубопроводы;

- оснащение системы электроснабжения источником запуска газодизельных электростанций (с подогревом газа);

- совершенствование дренажной системы с применением транспортируемой вакуумной установки.

\section{Baikal Research Journal}


Таблица 6

Выборка рабочей ведомости для системы фильтрации и сепарации газа, предназначенного для очистки и подачи газа на залерное устройство методом HAZOP

\begin{tabular}{|c|c|c|c|c|c|c|}
\hline $\begin{array}{c}\text { Управ- } \\
\text { ляющее } \\
\text { слово }\end{array}$ & $\begin{array}{l}\text { Откло- } \\
\text { нение }\end{array}$ & Причины & Последствия & $\begin{array}{c}\text { Защитные } \\
\text { мероприятия }\end{array}$ & Рекомендации & $\begin{array}{c}\text { При- } \\
\text { ори- } \\
\text { тет }\end{array}$ \\
\hline Нет & $\begin{array}{l}\text { Нет } \\
\text { потока } \\
\text { газа }\end{array}$ & $\begin{array}{l}\text { Разрыв трубо- } \\
\text { провода, } \\
\text { закрыт кран } \\
\text { на отводе от } \\
\text { магистраль- } \\
\text { ного газопро- } \\
\text { вода, закрыт } \\
\text { входной } \\
\text { коллектор } \\
\text { терминала }\end{array}$ & $\begin{array}{l}\text { Прекращение } \\
\text { подачи газа } \\
\text { потребителю, } \\
\text { аварийное } \\
\text { отключение } \\
\text { терминала га- } \\
\text { зодизельных } \\
\text { электростан- } \\
\text { ций. Эконо- } \\
\text { мические } \\
\text { потери }\end{array}$ & $\begin{array}{l}\text { Система обна- } \\
\text { ружения утечки } \\
\text { в трубопроводе и дей- } \\
\text { ствия по отсечению } \\
\text { аварийного участка } \\
\text { магистрального газо- } \\
\text { провода, аварийный } \\
\text { источник беспере- } \\
\text { бойного питания, } \\
\text { блокировка кранов } \\
\text { терминала в откры- } \\
\text { том состоянии }\end{array}$ & $\begin{array}{l}\text { Проанализиро- } \\
\text { вать вопрос об } \\
\text { әффективности } \\
\text { системы обнару- } \\
\text { жения утечек в } \\
\text { системе терми- } \\
\text { нала при исполь- } \\
\text { зовании линии } \\
\text { байпаса и отсе- } \\
\text { чении терминала } \\
\text { от магистрального } \\
\text { газопровода }\end{array}$ & 2 \\
\hline $\begin{array}{l}\text { Обрат- } \\
\text { но }\end{array}$ & $\begin{array}{l}\text { Обрат- } \\
\text { ный } \\
\text { поток } \\
\text { газа }\end{array}$ & $\begin{array}{l}\text { Открытие } \\
\text { линии сброса } \\
\text { давления } \\
\text { фильтра до } \\
\text { закрытия } \\
\text { клапанов на } \\
\text { выходном } \\
\text { потоке }\end{array}$ & $\begin{array}{l}\text { Разрушение } \\
\text { фильтра }\end{array}$ & $\begin{array}{l}\text { Переключение на } \\
\text { второй резервный } \\
\text { фильтр }\end{array}$ & $\begin{array}{l}\text { Проанализиро- } \\
\text { вать проектные } \\
\text { решения по } \\
\text { последствиям } \\
\text { и возможности } \\
\text { повышенной за- } \\
\text { щиты фильтра при } \\
\text { обратном потоке }\end{array}$ & 2 \\
\hline $\begin{array}{l}\text { Мень- } \\
\text { ше }\end{array}$ & $\begin{array}{l}\text { Умень- } \\
\text { шение } \\
\text { темпе- } \\
\text { ратуры }\end{array}$ & $\begin{array}{l}\text { Низкая } \\
\text { температура } \\
\text { окружающей } \\
\text { среды, } \\
\text { дросселирова- } \\
\text { ние }\end{array}$ & $\begin{array}{l}\text { Отказ } \\
\text { оборудова- } \\
\text { ния, } \\
\text { контрольно- } \\
\text { измеритель- } \\
\text { ных приборов } \\
\text { и автоматиза- } \\
\text { ции }\end{array}$ & $\begin{array}{l}\text { Климатические } \\
\text { условия учтены } \\
\text { расчетом, материал } \\
\text { корпуса рассчитан } \\
\text { на-46 }{ }^{\circ} \text {, а трубо- } \\
\text { провода и предохра- } \\
\text { нительного клапа- } \\
\text { на - на температуру } \\
125 \text { С на стороне } \\
\text { низкого давления }\end{array}$ & Не требуются & 2 \\
\hline
\end{tabular}

Составлено по: [11].

Таким образом, методы HAZID и HAZOP благодаря детальному анализу возможных отклонений, причин аварий и их последствий позволяют выявить потенциальные риски и разработать мероприятия по снижению вероятности их наступления. Управляя таким образом рисками на этапе проектирования завода, компании смогут снизить уровень аварийности на этапе его опытной эксплуатации, что позволит избежать человеческих жертв, штрафов, а также экологического ущерба окружающей среде.

\section{Список использованной литературы}

1. Ерёмин Ал. Н. Управление разработкой интеллектуальных месторождений нефти и газа : учеб. пособие : в 2 кн. / Ал. Н. Ерёмин, Ан. Н. Ерёмин, Н. А. Ерёмин. - М. : Изд-во Рос. гос. ун-та нефти и газа им. И. М. Губкина, 2012. - Кн. 2. -165 с.

2. Макарова Г. Н. «Скрытый» инвестиционный кризис в условиях российских реформ [Электронный ресурс] / Г. Н. Макарова // Известия Иркутской государственной экономической академии (Байкальский государственный университет экономики и права). - 2013. № 6. - Режим доступа : http://eizvestia.isea.ru/reader/article.aspx?id=\% 2018650.

3. Русецкая Г. Д. Методология анализа мирового энергетического рынка [Электронный peсурс] / Г. Д. Русецкая // Известия Иркутской государственной экономической академии

\section{Baikal Research Journal}


(Байкальский государственный университет экономики и права). - 2012. — № 4. - Режим доступа : http://eizvestia.isea.ru/reader/article.aspx?id=13860.

4. Тетельмин В. В. Попутный нефтяной газ. Технологии добычи, стратегии использования : учеб. пособие / В. В. Тетельмин, В. А. Язев, А. А. Совольянов. - М. : ИД Интеллект, 2013. $-208 \mathrm{c}$.

5. Blank S. Why Is Russian Energy Policy Failing in Asia? / S. Blank, Y. Kim // Pacific Focus. - 2011. - Vol. 26, iss. 3. - P. 406.

6. Сорокин Н. Д. Настольная книга эколога предприятия: государственный экологический надзор / Н. Д. Сорокин. - М. : Компания «Интеграл», $2014-611$ с.

7. Antonczyk R. C. Venture capital and risk perception / R. C. Antonczyk // Zeitschrift für Betriebswirtschaft. - 2012. - Vol. 82, № 4. - P. 389-416.

8. Finkel R. A. The masters of private equity and venture capital: management lessons from the pioneers of private investing / R. A. Finkel, D. Greising. - New York : McGraw-Hill, 2010. $-308 \mathrm{p}$.

9. Crawley Frank. HAZOP Guide to Best Practice / Frank Crawley, Brian Tyler. $-3^{\text {rd }}$ ed. Elsevier : Kidlington, 2015. - 159 p.

10. Project risk management guidelines. Managing risk in large projects and complex procurements / Dale F. Cooper, Grey Stephen, Raymond Geoffrey, Hfil Walker. — John Wiley \& Sons, Ltd. : Chippenham, 2011. - 384 p.

11. Howson P. Due Diligence: The Critical Stage in Mergers and Acquisitions / P. Howson. Gower Publishing Company, 2003. - 286 p.

12. Богомолова И. П. Формирование карты рисков деятельности технопарка / И. П. Богомолова, И. Н. Булгакова, О. А. Бернадская // Экономика и предпринимательство. — 2012. № 2 . - С. 263-265.

\section{References}

1. Eremin Al. N., Eremin An. N., Eremin H. A. Upravlenie razrabotkoi intellektual'nykh mestorozhdenii nefti $i$ gaza [Managing development of intellectual oil and gas deposits]. Moscow, Gubkin Russian State University of Oil and Gas Publ., 2012. B. 2. 165 p.

2. Makarova G. N. "Hidden» investment crisis in the context of Russian reforms. Izvestiya Irkutskoy gosudarstvennoy ekonomicheskoy akademii (Baykalskiy gosudarstvennyy universitet ekonomiki i prava) =Bulletin of Irkutsk State Economics Academy (Baikal State University of Economics and Law), 2013, no. 6. Available at: http://eizvestia.isea.ru/reader/article.aspx?id=\% 2018650. (In Russian).

3. Rusetskaya G. D. Methodology of the global energy market analysis. Izvestiya Irkutskoy go sudarstvennoy ekonomicheskoy akademii (Baykalskiy gosudarstvennyy universitet ekonomiki i pra$v a)=$ Bulletin of Irkutsk State Economics Academy (Baikal State University of Economics and Law), 2012, no. 4. Available at: http://eizvestia.isea.ru/reader/article.aspx?id=13860. (In Russian).

4. Tetelmin V. V., Yazev V. A., Sovolyanov A. A. Poputnyi neftyanoi gaz. Tekhnologii dobychi, strategii ispol'zovaniya [Associated oil gas. Technology of extraction, strategies of use]. Moscow, Intellekt Publ., 2013. 208 p.

5. Blank S., Kim Y. Why Is Russian Energy Policy Failing in Asia? Pacific Focus, 2011, vol. 26 , iss. 3 , p. 406.

6. Sorokin N. D. Nastol'naya kniga ekologa predpriyatiya: gosudarstvennyi ekologicheskii nadzor [A table book for a company's ecologist: governmental ecological supervision ]. Moscow, Integral Publ., 2014. 611 p.

7. Antonczyk R. C. Venture capital and risk perception. Zeitschrift für Betriebswirtschaft, 2012, vol. 82, no. 4, pp. 389-416.

8. Finkel R. A., Greising D. The masters of private equity and venture capital: management lessons from the pioneers of private investing. New York, McGraw-Hill, 2010. 308 p.

9. Crawley Frank, Tyler Brian. HAZOP Guide to Best Practice. $3^{\text {rd }}$ ed. Elsevier, Kidlington, 2015. $159 \mathrm{p}$.

10. Cooper Dale F., Stephen Grey, Geoffrey Raymond, Walker Hfil. Project risk management guidelines. Managing risk in large projects and complex procurements. John Wiley \& Sons, Ltd.: Chippenham, 2011. 384 p.

11. Howson P. Due Diligence: The Critical Stage in Mergers and Acquisitions. Gower Publishing Company, 2003. $286 \mathrm{p}$.

\section{Baikal Research Journal}


12. Bogomolova I. P., Bulgakova I. N., Bernadskaya O. A. Developing risk maps for techno park activities. Ekonomika i predprinimatel'stvo $=$ Economics and Entrepreneurship, 2012, no. 2, pp. 263-265. (In Russian).

\section{Информация об авторах}

Уразова Нина Геннадьевна - кандидат экономических наук, доцент, кафедра управления промышленными предприятиями, Иркутский национальный исследовательский технический университет, 664074, г. Иркутск, ул. Лермонтова, 83, e-mail: urazova_nina@mail.ru.

Мартынюк Алексей Владимирович - аспирант, кафедра управления промышленными предприятиями, Иркутский национальный исследовательский технический университет, 664074, г. Иркутск, ул. Лермонтова, 83, e-mail: alexmar.irk@gmail.com.

\section{Authors}

Nina G. Urazova - PhD in Economics, Associate Professor, Chair of Management of Industrial Companies, Irkutsk National Research Technical University, 83 Lermontov St., 664074, Irkutsk, Russian Federation; e-mail: urazova_nina@mail.ru.

Aleksey V. Martynyuk - PhD Student, Chair of Management of Industrial Companies, Irkutsk National Research Technical University, 83 Lermontov St., 664074, Irkutsk, Russian Federation; e-mail: alexmar.irk@gmail.com.

\section{Библиографическое описание статьи}

Уразова Н. Г. Управление рисками на этапе проектирования объектов переработки нефти и газа / Н. Г. Уразова, М. В. Мартынюк // Baikal Research Journal. — 2016. — Т. 7, № 2. DOI : $10.17150 / 2411-6262.2016 .7(2) .9$.

\section{Reference to article}

Urazova N. G., Martynyuk A. V. Risk management at the stage of designing facilities of rude oil and gas processing. Baikal Research Journal, 2016, vol. 7, no. 2. DOI: 10.17150/2411$\underline{6262.2016 .7(2) .9}$. (In Russian).

\section{Baikal Research Journal}

